\title{
PENGANTAR SEMANTIK \\ (PENGERTIAN, HAKIKAT, JENIS)
}

\author{
Surianti Nafinuddin \\ suriantiunismuh123@gmail.com
}

\begin{abstract}
Abstrak
Semantik dapat diartikan sebagai ilmu tentang makna atau tentang arti, yaitu satu dari tiga tataran analisis bahasa: fonologi, gramatikal, dan semantik. Kata semantik disepakati sebagai istilah yang digunakan untuk bidang linguistik yang mempelajari hubungan antara tanda-tanda linguistik tengan hal-hal yang ditandainya, atau dengan kata lain, bidang studi dalam linguistic yang mempelajari makna atau arti dalam bahasa. Semantik adalah cabang linguistic yang mempunyai hubungan erat dengan ilmu-ilmu sosial lain seperti sosiologi atau antropologi, bahkan juga dengan filsafat dan psikologi. Sosiologi mempunyai kepentiangan dengan semantic karena sering dijumpai kenyataan bahwa penggunaan kata-kata tertentu untuk mengatakan sesuatu makna dapat menandai identitas kelompok dalam masyarakat.
\end{abstract}

Keyword: semantik, makna, jenis semantik, manfaat semantik

\begin{abstract}
Semantics can be interpreted as the science of meaning or about meaning, which is one of the three levels of language analysis: phonological, grammatical, and semantic. The word semantics is agreed upon as a term used for the field of linguistics which studies the relationship between linguistic signs and the things they mark, or in other words, fields of study in linguistics that study meaning or meaning in language. Semantics is a branch of linguistics that has close relations with other social sciences such as sociology or anthropology, even with philosophy and psychology. Sociology has a rest with semantics because it is often found that the use of certain words to say something meaning can mark the identity of groups in society.
\end{abstract}

Keyword: semantics, meaning, semantic types, semantic benefits 


\section{Pengertian Semantik}

Ada dua cabang utama linguistik yang khusus menyangkut kata, yaitu etimologi (studi tentang asal usul kata) dan semantik (ilmu makna, studi tentang makna kata). Di antara kedua ilmu itu, etimologi sudah merupakan disiplin ilmu yang lama mapan (established), sedangkan semantik relatif merupakan hal yang baru.

Kata semantik berasal dari bahasa Yunani sema yang artinya tanda atau lambang (sign). "Semantik" pertama kali digunakan oleh seorang filolog Perancis bernama Michel Breal pada tahun 1883. Kata semantik kemudian disepakati sebagai istilah yang digunakan untuk bidang linguistik yang mempelajari tentang tanda-tanda linguistik dengan hal-hal yang ditandainya. Oleh karena itu, kata semantik dapat diartikan sebagai ilmu tentang makna atau tentang arti, yaitu salah satu dari tiga tataran analisis bahasa: fonologi, gramatika, dan semantik (Chaer, 1994: 2). Semantik (dari bahasa Yunani: semantikos, memberikan tanda, penting, dari kata sema, tanda) adalah cabang linguistik yang mempelajari arti/makna yang terkandung pada suatu bahasa, kode, atau jenis representasi lain. Dengan kata lain, semantik adalah pembelajaran tentang makna. Semantik biasanya dikaitkan dengan dua aspek lain: sintaksis, pembentukan simbol kompleks dari simbol yang lebih sederhana, serta pragmatik, penggunaan praktis simbol oleh komunitas pada konteks tertentu.

Kata semantik itu sendiri menunjukkan berbagai ide - dari populer yang sangat teknis. Hal ini sering digunakan dalam bahasa sehari-hari untuk menandakan suatu masalah pemahaman yang datang ke pemilihan kata atau konotasi. Masalah pemahaman ini telah menjadi subjek dari banyak pertanyaan formal, selama jangka waktu yang panjang, terutama dalam bidang semantik formal. Dalam linguistik, itu adalah kajian tentang interpretasi tanda-tanda atau simbol yang digunakan dalam agen atau masyarakat dalam keadaan tertentu dan konteks.[3] Dalam pandangan ini, suara, ekspresi wajah, bahasa tubuh, dan proxemics memiliki semantik konten (bermakna), dan masing-masing terdiri dari beberapa cabang kajian. Dalam bahasa tertulis, hal-hal seperti struktur ayat dan tanda baca menanggung konten semantik, bentuk lain dari bahasa menanggung konten semantik lainnya.

Sebuah kata, misalnya buku, terdiri atas unsur lambang bumyi yaitu [b-u-k-u] dan konsep atau citra mental benda-benda (objek) yang dinamakan buku. Menurut Ogden dan Richards (1923), dalam karya klasik tentang "teori semantik segi tiga" , kaitan antara lambang, citra mental atau konsep, dan referen atau objek dapat dijelaskan dengan gambar dan uraian sebagai berikut.

Citra mental/konsep buku

Lambang [b-u-k-u] Referen/objek 


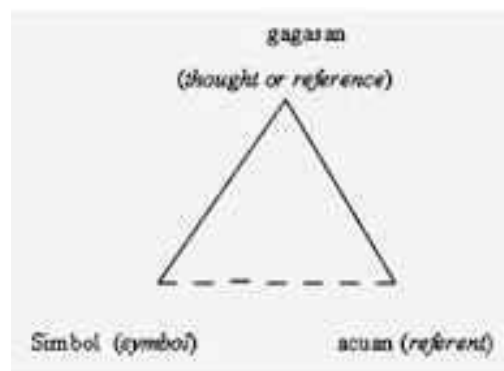

Gambar 1. Konsep segitiga

Makna kata buku adalah konsep buku yang tersimpan dalam otak kita dan dilambangkan dengan kata buku. Gambar di samping menunjukkan bahwa di antara lambang bahasa dan konsep terdapat hubungan langsung, sedangkan lambang bahasa dengan referen atau objeknya tidak berhubungan langsung

(digambarkan dengan garis putus-putus) karena harus melalui konsep. Dengan demikian, dapat disimpulkan bahwa semantik mengkaji makna tanda bahasa, yaitu kaitan antara konsep dan tanda bahasa yang melambangkannya.

Dalam analisis semantik juga harus disadari, karena bahasa itu bersifat unik, dan mempunyai hubungan yang sangat erat dengan masalah budaya maka, analisis suatu bahasa hanya berlaku untuk bahasa itu saja, tetapi tidak dapat digunakan untuk menganalisis bahasa lain. Umpamanya, kata ikan dalam bahasa Indonesia merujuk pada jenis binatang yang hidup dalam air dan biasa dimakan sebagai lauk; dan dalam bahasa Inggris separan dengan fish. Tetapi kata iwak dalam bahasa Jawa bukan hanya berarti 'ikan' atau 'fish', melainkan juga berarti daging yang digunakan sebagai lauk.

Semantik kebahasaan adalah kajian tentang makna yang digunakan untuk memahami ekspresi manusia melalui bahasa. Bentuk lain dari semantik mencakup semantik bahasa pemrograman, logika formal, dan semiotika.

Kajian formal semantik bersinggungan dengan banyak bidang penyelidikan lain, termasuk leksikologi, sintaksis, pragmatik, etimologi dan lain-lain, meskipun semantik adalah bidang yang didefinisikan dengan baik dalam dirinya sendiri, sering dengan sifat sintetis Dalam filsafat bahasa, semantik dan referensi berhubungan erat. Bidang-bidang terkait termasuk filologi, komunikasi, dan semiotika. Kajian formal semantik karena itu menjadi kompleks.

Semantik berbeda dengan sintaksis, kajian tentang kombinatorik unit bahasa (tanpa mengacu pada maknanya), dan pragmatik, kajian tentang hubungan antara simbol-simbol bahasa, makna, dan pengguna bahasa.

Dalam kosakata ilmiah internasional, semantik juga disebut semasiologi.

Pengertian Semantik Menurut Para Ahli

Berikut ini terdapat beberapa pengertian semantik menurut para ahli, terdiri atas: 
a. Menurut Ferdinand de saussure (1966)

Mengemukakan semantik yaitu yang terdiri dari (1) komponen yang mengartikan, yang berwujud bentuk-bentuk bunyi bahasa dan (2) komponen yang diartikan atau makna dari komponen yang pertama itu. Kedua komponen ini adalah merupakan tanda atau lambang, sedangkan yang ditandai atau atau yang dilambanginya adalah sesuatu yang berbeda diluar bahsa yang lazim disebut referen atau hal yang ditunjuk.

b. Menurut Tarigan (1985: 2)

Mengatakan bahwa semantik dapat dipakai dalam pengertian luas dan dalam pengertian sempit. Semantik dalam arti sempit dapat diartikan sebagai telaah hubungan tanda dengan objek-objek yang merupakan wadah penerapan tanda-tanda tersebut.

c. Menurut Verharr (2001: 384)

Dapat dibedakan menjadi dua, yaitu semantik gramatikal dan semantik leksikal. Istilah semantik ini digunakan para ahli bahasa untuk menyebut salah satu cabang ilmu bahsa yang bergerak pada tataran makna atau ilmu bahsa yang mempelajari makna.

d. Menurut Chaer (2009: 6-11)

Semantik berdasarkan tataran atau bagian dari bahasa yang menjadi objek penyelidikan dapat dibedakan menjadi empat, yaitu (1) semantik leksikal yang merupakan jenis semantik yang objek penelitiannya adalah leksikon dari suatu bahsa, (2) semantik gramatikal yang merupakan jenis semantik yang objek penelitiannya adalah makna-makna gramatikal dari tataran morfologi, (3) semantik sintaksikal yang merupakan jenis semantik yang sasaran penyelidikannya bertumpu pada hal-hal yang berkaitan dengan sintaksis, (4) semantik maksud yang merupakan jenis semantik yang berkenaan dengan pemakaian bentuk-bentuk gaya bahsa, seperti metafora, ironi, litotes, dan sebagainya.

e. Menurut Charles Morrist

Mengemukakan bahwa semantik menelaah "hubungan-hubungan tanda-tanda dengan objek-objek yang merupakan wadah penerapan tanda-tanda tersebut".

f. Menurut J.W.M Verhaar; 1981:9

Mengemukakan bahwa semantik (inggris: semantics) berarti teori makna atau teori arti, yakni cabang sistematik bahasa yang menyelidiki makna atau arti.

g. Menurut Lehrer; 1974: 1

Semantik adalah studi tentang makna. Bagi Lehrer, semantik merupakan bidang kajian yang sangat luas, karena turut menyinggung aspek-aspek struktur dan fungsi bahasa sehingga dapat dihubungkan dengan psikologi, filsafat dan antropologi.

h. Menurut Kambartel (dalam Bauerk, 1979: 195) 
Semantik mengasumsikan bahwa bahasa terdiri dari struktur yang menampakan makna apabila dihubungkan dengan objek dalam pengalaman dunia manusia.

i. Menurut Ensiklopedia britanika (Encyclopedia Britanica, vol.20, 1996: 313)

Semantik adalah studi tentang hubungan antara suatu pembeda linguistik dengan hubungan proses mental atau simbol dalam aktifitas bicara.

j. Menurut Dr. Mansoer pateda

Semantik adalah subdisiplin linguistik yang membicarakan makna.

k. Menurut Abdul Chaer

Semantik adalah ilmu tentang makna atau tentang arti. Yaitu salah satu dari 3 (tiga) tataran analisis bahasa (fonologi, gramatikal dan semantik).

I. Ferdinand de Saussure (1966)

Semantik terdiri dari:

$\star$ Komponen yang mengartikan, yang berwujud bentuk dan bunyi bahasa.

$\star$ Komponen yang diartikan atau makna dari komponen yang pertama itu.

m. Menurut Drs. Aminuddin, M.Pd

Semantik mengandung pengertian studi tentang makna dengan anggapan bahwa makna menjadi bagian dari bahasa, maka semantic merupakan bagian dari linguistik.

\section{Hakikat Makna}

Menurut teori yang dikembangkan dari pandangan Ferdinand de Saussure, makna adalah 'pengertian' atau 'konsep' yang dimiliki atau terdapat pada sebuah tanda-linguistik. Menurut de Saussure, setiap tanda linguistik terdiri dari dua unsur, yaitu (1) yang diartikan (Perancis: signifie, Inggris: signified) dan (2) yang mengartikan (Perancis: signifiant, Inggris: signifier). Yang diartikan (signifie, signified) sebenarnya tidak lain dari pada konsep atau makna dari sesuatu tanda-bunyi. Sedangkan yang mengartikan (signifiant atau signifier) adalah bunyi-bunyi yang terbentuk dari fonem-fonem bahasa yang bersangkutan. Dengan kata lain, setiap tanda-linguistik terdiri dari unsur bunyi dan unsur makna. Kedua unsur ini adalah unsur dalam-bahasa (intralingual) yang biasanya merujuk atau mengacu kepada sesuatu referen yang merupakan unsur luar-bahasa (ekstralingual).

Dalam bidang semantik istilah yang biasa digunakan untuk tanda-linguistik itu adalah leksem, yang lazim didefinisikan sebagai kata atau frase yang merupakan satuan bermakna (Harimurti, 1982:98). Sedangkan istilah kata,yang lazim didefinisikan sebagai satuan bahasa yang dapat berdiri sendiri yang dapat terjadi dari morfem tunggal atau gabungan morfem (Harimurti, 1982:76) adalah istilah dalam bidang gramatika. Dalam makalah ini kedua istilah itu dianggap memiliki pengertian yang sama. 
Yang perlu dipahami adalah tidak semua kata atau leksem itu mempunyai acuan konkret di dunia nyata. Misalnya leksem seperti agama, cinta, kebudayaan, dan keadilan tidak dapat ditampilkan referennya secara konkret. Di dalam penggunaannya dalam pertuturan, yang nyata makna kata atau leksem itu seringkali, dan mungkin juga biasanya, terlepas dari pengertian atau konsep dasarnya dan juga dari acuannya. Misal kata buaya dalam kalimat (1).

(1). Dasar buaya, ibunya sendiri ditipunya.

Oleh karena itu, kita baru dapat menentukan makna sebuah kata apabila kata itu sudah berada dalam konteks kalimatnya. Makna sebuah kalimat baru dapat ditentukan apabila kalimat itu berada di dalam konteks wacananya atau konteks situasinya. Contoh, seorang setelah memeriksa buku rapor anaknya dan melihat angka-angka dalam buku rapor itu banyak yang merah, berkata kepada anaknya dengan nada memuji.

(2). "Rapormu bagus sekali, Nak!"

Jelas, dia tidak bermaksud memuji walaupun nadanya memuji. Dengan kalimat itu dia sebenarnya bermaksud menegur tau mungkin mengejek anaknya itu.

\section{Perkembangan Pemerolehan Semantik}

Clark (1977) secara umum menyimpulkan perkembangan pemerolehan semantik ini kedalam emapt tahap, yaitu :

\section{Tahap penyempitan makna kata}

Tahap ini berlangsung antara umur satu sampai satu setengah tahun ( 1:0 - 1:6). Pada tahap ini kanakkanak menganggap satu benda tertentu yang dicakup oleh satu makna menjadi nama dari benda itu. Jadi, yang disebut ( meong) hanyalah kucing yang dipelihara di rumah saja. Begitu juga ( gukguk ) hanyalah anjing yang ada dirumah saja, tidak termasuk yang berada di luar rumah si anak.

\section{Tahap Generalisasi berlebihan}

Tahap ini berlangsung antara usia satu tahun setengah sampai dua tahun setengah (1:6 - 2:6). Pada tahap ini kanak-kanak mulai menggeneralisasikan makna suatu kata secara berlebihan. Jadi, yang dimaksud dengan anjing atau gukguk dan kucing atau meong adalah semua binatang yang berkaki empat, termasuk kambinh dan kerbau.

\section{Tahap medan semantik}

Tahap ini berlangsung antara usia dua tahun setengah sampai limatahun ( 2:6 - 5:0). Pada tahap ini kanak-kanak mulai mengelompokkan kata-kata yang berkaitan ke dalam satu medansemantik. Pada mulanya proses ini berlangsung jika makna kata-kata yang digeneralisasi secara berlebihan semakin 
sedikit setelah kata-kata baru untuk benda-benda yang termasuk dalam generalisasi ini dikuasai oleh kanak-kanak.

Umpamanya, kalau pada mualanya kata anjing berlaku untuk semua binatang berkaki empat ; namun, stelah mereka mengenal kata kuda, kambing, dan harimau, maka anjing hanya berlaku untuk anjing saja.

\section{Tahap generalisasi}

Tahap ini berlangsung setelah kanak-kanak berusia lima tahun. Pada tahap ini kanak-kanak telah mulai mampu mengenal benda-benda yang sama dari sudut persepsi, bahwa benda-benda itu mempunyai fitur-fitur semantic yang sama.

Pengenalan ini semakin sempurna jika kanak-kanak semakin bertanbah usianya. Jadi, ketika berusia antara 5 - 7 tahun mereka telah mampu mengenal yang dimaksud dengan heawan, yaitu semua mahluk yang termasuk hewan.

Dari penjelasan di atas terlihat bahwa kanak-kanak membutuhkan tahap-tahapan dalam memperoleh makna semantik, dan lingkungan sangat membentu kanak-kanak untuk memperoleh makna tersebut, karena dalam proses pemerolehan itu kanak-kanak menggunakan indranya. Jadi, semakin banyak kanakkanak mengamati lingkungannya akan sangat membantu sekali dalam memperolah makna kata-kata dari suatu konsep.

\section{Jenis Semantik}

Telah dijelaskan bahwa semantik adalah disiplin linguistik yang mengkaji sistem makna. Jadi, objeknya makna. Makna yang dikaji dalam semantik dapat dikaji dari banyak segi, terutama teori atau aliran yang berbeda dalam linguistik.

Teori yang mendasari dan dalam lingkungan mana semantik dibahas membawa kita kepengenalan tentang jenis-jenis semantik. Jenis-jenis semantik itu dapat dideskripsikan berikut ini:

\section{Semantik Behavioris}

Para penganut aliran behavioris memiliki sikap umum:

Penganut pandangan behavioris tidak terlalu yakin dengan istilah-istilah yang bersifat mentalistik berupa mind, concept, dan idea:

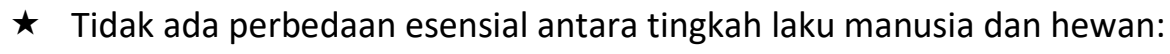

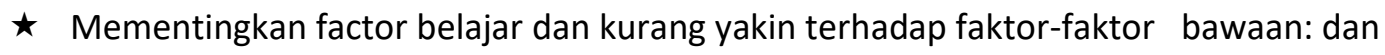

$\star$ Mekanismenya atau determinasinya.

Berdasarkan sketsa itu makna berada dalam rentangan antara stimulus dan respon, antara rangsangan dan jawaban. Makna ditentukan oleh situasi yang berarti ditentukan oleh lingkungan. Karena itu, makna hanya dapat dipahami jika ada data yang dapat diamati yang berada dalam lingkungan pengalaman manusia. 
Contoh: seorang ibu yang menyuapkan makanan pada sibayi.

\section{Semantik Deskriptif}

Semantik deskriptif yaitu kajian semantik yang khusus memperlihatkan makna yang sekarang berlaku. Makna kata ketika kata itu untuk pertama kali muncul. Tidak diperhatikan. Misalnya dalam bahasa Indonesia ada kata juara yaitu orang yang mendapat peringkat teratas dalam pertandingan tanpa memperhatikan makna sebelumnya yaitu pengatur atau pelerai dalam persabungan ayam. Jadi, Semantik deskriptif hanya memperhatikan makna sekarang.

\section{Semantik Generatif}

Konsep-konsep yang terkenal dalam aliran ini adalah:

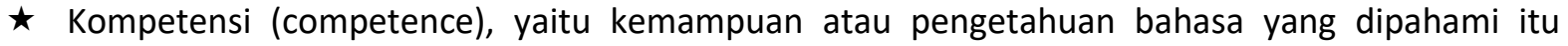
dalam komunikasi:

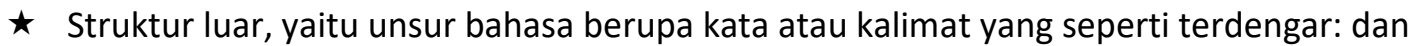

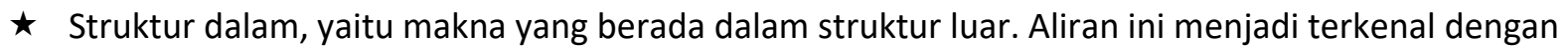
munculnya buku Chomsky tahun 1957 yang kemudian diperbarui.

Teori semantic generatif muncul tahun 1968 karena ketidak puasan linguis terhadap pendapat Chomsky. Menurut pendapat mereka struktur semantik dan struktur sintaksis bersifat homogen. Struktur dalam tidak sama dengan struktur semantik.

Untuk menghubungkannya digambarkan dengan satu kaidah, yaitu transformasi. Teori ini tiba pada kesimpulan bahwa tata bahasa terdiri dari struktur dalam yang berisi tidak lain dari struktur semantik dan struktur luar yang merupakan perwujudan ujaran kedua struktur ini dihubungkan dengan suatu proses yang disebut transformasi.

\section{Semantik Gramatikal}

Semantik gramatikal adalah studi simentik yang khususnya mengkaji makna yang terdapat dalam satuan kalimat. Verhaar mengatakan Semantik gramatikal jauh lebih sulit dianalisis. Untuk menganalisis kalimat masih duduk, kakak sudah tidur tidak hanya ditafsirkan dari kata-kata yang menyusunnya.

Orang harus menafsirkan keseluruhan isi kalimat itu serta sesuatu yang ada dibalik kalimat itu. Sebuah kata akan bergesr maknanya apabila diletakkan atau digabungkan dengan kata lain.

\section{Semantik Leksikal}

Semantik leksikal adalah kajian simentik yang lebih memuaskan pada pembahasan sistem makna ayang terdapat dalam kata. Semantik leksikal tidak terlalu sulit. Sebuah kamus merupakan contoh yang tepat untuk Semantik leksikal: makna setiap kata diuraikan disitu. Jadi, Semantik leksikal memperhatikan makna yang terdapat didalam kalimat kata sebagai satuan mandiri. 


\section{Semantik Historis}

Semantik historis adalah studi semantik yang mengkaji sistem makna dalam rangkaian waktu. Studi semantik historis ini menekankan studi makna dalam rentangan waktu, bukan perubahan bentuk kata. Perubahan bentuk kata lebih banyak dikaji dalam linguistic hoistoris.

Asal-usul kata menjadi bagian studi etimilogi. Semantik ini membandingkan kata-kata berdasarkan periode atau antara kata pada masa tertentu dengan kata pada bahasa yang lain. Misalnya dalam BI terdapat kata padi dan dalam bahasa jawa terdapat kata pari. Fonem/ d/ dan/r/ berkorespondensi.

\section{Semantik Logika}

Sematik logika adalah cabang logika modern yang berkaitan dengan konsep-konsep dan notasi simbolik dalam analisis bahasa semantik logika mengkaji sistem makna yang dilihat dari logika seperti yang berlaku dalam matematika yang mangacu kepada kata pengkajian makna atau penafsiran ajaran, terutama yang dibentuk dalam sistem logika yang oleh Carnap disebut semantik.

Dalam semantik logika dibahas makna proprsi yang dibedakan dengan kalimat, sebab kalimat yang berbeda dalam bahasa yang sama dapat aja diujarkan dalam proporsi yang sama. Sebaliknya, sebuah kalimat dapat diujarkan dalam dua atau lebih proporsi. Proporsi boleh benar boleh salah, dan lambang disebut sebagai variabel proporsional dalam semantik logika.

\section{Semantik Struktural}

Semantik struktural bermula dari pandangan linguis struktural yang dipelopori oleh Saussure. Penganut strukturalisme berpendapat bahwa setiap bahasa adalah sebuah sistem, sebuah hubungan struktur yang unik yang terdiri dari satuan-satuan yang disebut struktur. Struktur itu terjelma dalam unsure berupa fonem, morfem, kata, frase, klausa, kalimat, dan wacana yang membaginya menjadi kajian fonologi, morfologi, sintaksis, dan wacana.

\section{Manfaat Semantik}

Berikut ini terdapat tiga (3) manfaat semantik, terdiri atas:

^ Bagi seorang wartawan, seorang reporter atau orang-orang yang berkecimpung dalam dunia persuratkabaran dan pemberitaan, mereka barang kali akan memperoleh manfaat praktis dari mengenai semantik. Pengetahuan semantik akan memudahkannya dalam memilih dan menggunakan kata dengan makna yang tepat dalam menyampaikan informasi kepada masyarakat umum. Tanpa pengetahuan akan konsep-konsep polisemi, homonimi, denotasi, konotasi dan nuansa-nuansa makna tertentu akan sulit bagi mereka untuk dapat menyampaikan informasi secara tepat dan benar. 
^ Bagi mereka yang berkecimpung dalam penelitian bahasa, seperti mereka yang belajar di Fakultas Sastra, pengetahuan semantik akan banyak memberi bekal teoretis kepadanya untuk dapat menganalisis bahasa atau bahasa-bahasa yang sedang dipelajarinya.

* Bagi seorang guru atau calon guru pengetahuan semantik mengenai semantik akan memberi manfaat teoretis dan juga manfaat praktis. Manfaat teoretis karena dia sebagai guru bahasa harus pula mempelajari dengan sungguh-sungguh akan bahasa yang diajarkannya. Teori-teori semantik ini akan menolong memahami dengan baik "rimba belantara rahasia" bahasa yang akan diajarkannya itu. Sedangkan manfaat praktis akan diperolehnya berupa kemudahan bagi dirinya dalam mengajarkan bahasa itu kepada murid-muridnya. Sorang guru bahasa, selain harus memiliki pengetahuan dan keterampilan yang luas mengenai segala aspek bahasa, juga harus memiliki pengetahuan teori semantik secara memadai.

\section{Jenis Makna}

Menurut Chaer (1994), makna dapat dibedakan berdasarkan beberapa kriteria dan sudut pandang. Berdasarkan jenis semantiknya, dapat dibedakan antara makna leksikal dan makna gramatikal, berdasarkan ada atau tidaknya referen pada sebuah kata atau leksem dapat dibedakan adanya makna referensial dan makna nonreferensial, berdasarkan ada tidaknya nilai rasa pada sebuah kata/leksem dapat dibedakan adanya makna denotatif dan makna konotatif, berdasarkan ketepatan maknanya dikenal makna kata dan makna istilah atau makna umum dan makna khusus. Lalu berdasarkan kriteri lain atau sudut pandang lain dapat disebutkan adanya makna-makna asosiatif, kolokatif, reflektif, idiomatik dan sebagainya.

\section{Makna Leksikal dan Makna Gramatikal}

Leksikal adalah bentuk adjektif yang diturunkan dari bentuk nomina leksikon. Satuan dari leksikon adalah leksem, yaitu satuan bentuk bahasa yang bermakna. Kalau leksikon kita samakan dengan kosakata atau perbendaharaan kata, maka leksem dapat kita persamakan dengan kata. Dengan demikian, makna leksikal dapat diartikan sebagai makna yang bersifat leksikon, bersifat leksem, atau bersifat kata. Lalu, karena itu, dapat pula dikatakan makna leksikal adalah makna yang sesuai dengan referennya, makna yang sesuai dengan hasil observasi alat indera, atau makna yang sungguh-sungguh nyata dalam kehidupan kita (Chaer, 1994). Umpamanya kata tikus makna leksikalnya adalah sebangsa binatang pengerat yang dapat menyebabkan timbulnya penyakit tifus. Makna ini tampak jelas dalam kalimat Tikus itu mati diterkam kucing, atau Panen kali ini gagal akibat serangan hama tikus.

Makna leksikal biasanya dipertentangkan dengan makna gramatikal. Kalau makna leksikal berkenaan dengan makna leksem atau kata yang sesuai dengan referennya, maka makna gramatikal ini adalah makna yang hadir sebagai akibat adanya proses gramatika seperti proses afiksasi, proses reduplikasi, dan proses komposisi (Chaer, 1994). Proses afiksasi awalan ter- pada kata angkat dalam kalimat Batu seberat itu terangkat juga oleh adik, melahirkan makna 'dapat', dan dalam kalimat Ketika balok itu ditarik, papan itu terangkat ke atas melahirkan makna gramatikal 'tidak sengaja'.

2. Makna Referensial dan Nonreferensial 
Perbedaan makna referensial dan makna nonreferensial berdasarkan ada tidak adanya referen dari kata-kata itu. Bila kata-kata itu mempunyai referen, yaitu sesuatu di luar bahasa yang diacu oleh kata itu, maka kata tersebut disebut kata bermakna referensial. Kalau kata-kata itu tidak mempunyai referen, maka kata itu disebut kata bermakna nonreferensial. Kata meja termasuk kata yang bermakna referensial karena mempunyai referen, yaitu sejenis perabot rumah tangga yang disebut 'meja'. Sebaliknya kata karena tidak mempunyai referen, jadi kata karena termasuk kata yang bermakna nonreferensial.

\section{Makna Denotatif dan Konotatif}

Makna denotatif pada dasarnya sama dengan makna referensial sebab makna denotatif lazim diberi penjelasan sebagai makna yang sesuai dengan hasil observasi menurut penglihatan, penciuman, pendengaran, perasaan, atau pengalaman lainnya. Jadi, makna denotatif ini menyangkut informasiinformasi faktual objektif. Oleh karena itu, makna denotasi sering disebut sebagai 'makna sebenarnya'(Chaer, 1994). Umpama kata perempuan dan wanita kedua kata itu mempunyai dua makna yang sama, yaitu 'manusia dewasa bukan laki-laki'.

Sebuah kata disebut mempunyai makna konotatif apabila kata itu mempunyai "nilai rasa", baik positif maupun negatif. Jika tidak memiliki nilai rasa maka dikatakan tidak memiliki konotasi. Tetapi dapat juga disebut berkonotasi netral. Makna konotatif dapat juga berubah dari waktu ke waktu. Misalnya kata ceramah dulu kata ini berkonotasi negatif karena berarti 'cerewet', tetapi sekarang konotasinya positif.

\section{Makna Kata dan Makna Istilah}

Setiap kata atau leksem memiliki makna, namun dalam penggunaannya makna kata itu baru menjadi jelas kalau kata itu sudah berada di dalam konteks kalimatnya atau konteks situasinya. Berbeda dengan kata, istilah mempunyai makna yang jelas, yang pasti, yang tidak meragukan, meskipun tanpa konteks kalimat. Oleh karena itu sering dikatakan bahwa istilah itu bebas konteks. Hanya perlu diingat bahwa sebuah istilah hanya digunakan pada bidang keilmuan atau kegiatan tertentu. Perbedaan antara makna kata dan istilah dapat dilihat dari contoh berikut

(1) Tangannya luka kena pecahan kaca.

(2) Lengannya luka kena pecahan kaca.

Kata tangan dan lengan pada kedua kalimat di atas adalah bersinonim atau bermakna sama. Namun dalam bidang kedokteran kedua kata itu memiliki makna yang berbeda. Tangan bermakna bagian dari pergelangan sampai ke jari tangan; sedangkan lengan adalah bagian dari pergelangan sampai ke pangkal bahu.

\section{Makna Konseptual dan Makna Asosiatif}

Leech (1976) membagi makna menjadi makna konseptual dan makna asosiatif. Yang dimaksud dengan makna konseptual adalah makna yang dimiliki oleh sebuah leksem terlepas dari konteks atau asosiasi apa pun. Kata kuda memiliki makna konseptual 'sejenis binatang berkaki empat yang biasa dikendarai'. 
Jadi makna konseptual sesungguhnya sama saja dengan makna leksikal, makna denotatif, dan makna referensial.

Makna asosiatif adalah makna yang dimiliki sebuah leksem atau kata berkenaan dengan adanya hubungan kata itu dengan sesuatu yang berada di luar bahasa. Misalnya, kata melati berasosiasi dengan sesuatu yang suci atau kesucian.

\section{Makna Idiomatikal dan Peribahasa}

Idiom adalah satuan ujaran yang maknanya tidak dapat "diramalkan" dari makna unsur-unsurnya, baik secara leksikal maupun secara gramatikal. Contoh dari idiom adalah bentuk membanting tulang dengan makna 'bekerja keras', meja hijau dengan makna 'pengadilan'.

Berbeda dengan idiom, peribahasa memiliki makna yang masih dapat ditelusuri atau dilacak dari makna unsur-unsurnya karena adanya "asosiasi" antara makna asli dengan maknanya sebagai peribahasa. Umpamanya peribahasa Seperti anjing dengan kucing yang bermakna 'dikatakan ihwal dua orang yang tidak pernah akur'. Makna ini memiliki asosiasi, bahwa binatang yang namanya anjing dan kucing jika bersua memang selalu berkelahi, tidak pernah damai.

\section{Makna Kias}

Dalam kehidupan sehari-hari, penggunaan istilah arti kiasan digunakan sebagai oposisi dari arti sebenarnya. Oleh karena itu, semua bentuk bahasa (baik kata, frase, atau kalimat) yang tidak merujuk pada arti sebenarnya (arti leksikal, arti konseptual, atau arti denotatif) disebut mempunyai arti kiasan. Jadi, bentuk-bentuk seperti puteri malam dalam arti 'bulan', raja siang dalam arti 'matahari'.

\section{Relasi Makna}

disebut relasi makna. Relasi makna dapat berwujud macam-macam. Berikut ini diuraikan beberapa wujud relasi makna.

\section{Sinonimi}

Secara semantik Verhaar (1978) mendefinisikan sinonimi sebagai ungkapan (bisa berupa kata, frase, atau kalimat) yang maknanuya kurang lebih sama dengan makna ungkapan lain. Umpamanya kata buruk dan jelek adalah du buah kata yang bersinonim; bunga, kembang, dan puspa adalah tiga kata yang yang bersinonim. Hubungan makna antara dua buah kata yang bersinonim bersifat dua arah. Namun, dua buah kata yang bersinonim itu; kesamaannya tidak seratus persen, hanya kurang lebih saja. Kesamaannya tidak bersifat mutlak.

\section{Antonimi dan Oposisi}

Secara semantik Verhaar (1978) mendefenisikan antonimi sebagai: Ungkapan (biasanya berupa kata, tetapi dapat pula dalam bentuk frase atau kalimat) yang maknanya dianggap kebalikan dari makna ungkapan lain. Misalnya kata bagus yang berantonimi dengan kata buruk; kata besar berantonimi dengan kata kecil. 
Sama halnya dengan sinonim, antonim pun tidak bersifat mutlak. Itulah sebabnya dalam batasan di atas, Verhaar menyatakan "...yang maknanya dianggap kebalikan dari makna ungkapan lain" Jadi, hanya dianggap kebalikan. Bukan mutlak berlawanan.

Sehubungan dengan ini banyak pula yang menyebutnya oposisi makna. Dengan istilah oposisi, maka bisa tercakup dari konsep yang betul-betul berlawanan sampai kepada yang bersifat kontras saja. Kata hidup dan mati, mungkin bisa menjadi contoh yang berlawanan; tetapi hitam dan putih mungkin merupakan contoh yang hanya berkontras.

\section{Homonimi, Homofoni, dan Homografi}

Homonimi adalah 'relasi makna antar kata yang ditulis sama atau dilafalkan sama, tetapi maknanya berbeda'. Kata-kata yang ditulis sama tetapi maknanya berbeda disebut homograf, sedangkan yang dilafalkan sama tetapi berbeda makna disebut homofon. Contoh homograf adalah kata tahu (makanan) yang berhomografi dengan kata tahu (paham), sedang kata masa (waktu) berhomofoni dengan massa (jumlah besar yang menjadi satu kesatuan).

\section{Hiponimi dan Hipernimi}

Hiponimi adalah 'relasi makna yang berkaitan dengan peliputan makna spesifik dalam makna generis, seperti makna anggrek dalam makna bunga, makna kucing dalam makna binatang'. Anggrek, mawar, dan tulip berhiponimi dengan bunga, sedangkan kucing, kambing, dan kuda berhiponimi dengan binatang. Bunga merupakan superordinat (hipernimi, hiperonim) bagi anggrek, mawar, dan tulip, sedangkan binatang menjadi superordinat bagi kucing, kambing, dan kuda.

\section{Polisemi}

Polisemi lazim diartikan sebagai satuan bahasa (terutama kata, bisa juga frase) yang memiliki makna lebih dari satu. Umpamanya kata kepala dalam bahasa Indonesia memiliki makna (1) bagian tubuh dari leher ke atas; (2) bagian dari suatu yang terletak disebelah atas atau depan merupakan hal yang penting atau terutama seperti pada kepala susu, kepala meja, dan kepala kereta api; (3) bagian dari suatu yang berbentuk bulat seperti kepala, seperti pada kepala paku dan kepala jarum; (4) pemimpin atau ketua seperti pada kepala sekolah, kepala kantor, dan kepala stasiun; (5) jiwa atau orang seperti dalam kalimat Setiap kepala menerima bantuan Rp 5000,-.; dan (6) akal budi seperti dalam kalimat, Badannya besar tetapi kepalanya kosong.

\section{Ambiguitas}

Ambiguitas atau ketaksaab sering diartikan sebagai kata yang bermakna ganda atau mendua arti. Kegandaan makna dalam ambiguitas berasal dari satuan gramatikal yang lebih besar, yaitu frase atau kalimat dan terjadi sebagai akibat penafsiran struktur gramatikal yang berbeda. Umpamanya frase buku sejarah baru dapat ditafsirkan sebagai (1) buku sejarah itu baru terbit, (2) buku itu berisi sejarah zaman baru.

7. Redundansi 
Istilah redundansi sering diartikan sebagai 'berlebih-lebihan pemakaian unsur segmental dalam suatu bentuk ujaran'. Umpamanya kalimat Bola ditendang Si Badrih, maknanya tidak akan berubah bila dikatakan Bola ditendang oleh Si Badrih. Pemakaian kata oleh pada kalimat kedua dianggap sebagai sesuatu yang redundansi, yang berlebih-lebihan dan sebenarnya tidak perlu.

\section{Meronimi}

Meronimi adalah 'relasi makna yang memiliki kemiripan dengan hiponimi karena relasi maknanya bersifat hierarkis, namun tidak menyiratkan pelibatan searah, tetapi merupakan relasi makna bagian dengan keseluruhan'. Contohnya adalah atap bermeronimi dengan rumah.

\section{Makna Asosiatif}

Makna asosiatif merupakan asosiasi yang muncul dalam benak seseorang jika mendengar kata tertentu. Asosiasi ini dipengaruhi unsur-unsur psikis, pengetahuan dan pengalaman seseorang. Oleh karena itu, makna asosiatif terutama dikaji bidang psikolinguistik. Makna denotatif villa adalah 'rumah peristirahatan di luar kota'. Selain makna denotatif itu, bagi kebanyakan orang Indonesia villa juga mengandung makna asosiatif 'gunung', 'alam', 'pedesaan', 'sungai', bergantung pada pengalaman seseorang.

\section{Makna Afektif}

Makna afektif berkaitan dengan perasaan seseorang jika mendengar atau membaca kata tertentu. Perasaan yang muncul dapat positif atau negatif. Kata jujur, rendah hati, dan bijaksana menimbulkan makna afektif yang positif, sedangkan korupsi dan kolusi menimbulkan makna afektif yang negatif.

\section{Makna Etimologis}

Makna etimologis berbeda dengan makna leksikal karena berkaitan dengan asal-usul kata dan perubahan makna kata dilihat dari aspek sejarah kata. Makna etimologis suatu kata mencerminkan perubahan yang terjadi dengan kata tertentu. Melalui perubahan makna kata, dapat ditelusuri perubahan nilai, norma, keadaan sosial-politik, dan keadaan ekonomi suatu masyarakat.

Masalah pada Penamaan dan Pelabelan Dalam Semantik Linguistik

Menurut Robert Palmer (2010), penamaan dan penafsiran sebuah objek lebih mudah dilakukan pada kelas kata benda (nomina), tetapi akan terasa sulit pada kelas kata sifat (adjektiva) dan kerja (verba), kata benda tidak nyata, kata benda abstrak, dan kata benda yang memiliki makna terkait dengan lainnya.[6]

1. Kesulitan pada nomina dan adjektiva.

Contoh:

Kata Adjektiva: cantik, terkenal, baik, jahat.

Kata Verba: Berlari, bekerja, melihat, dsb. 
Kata-kata ini dianggap sulit untuk menemukan karakteristik-karakteristiknya secara terperinci. Misalnya pada kata lari, seseorang harus membayangkan terlebih dahulu apa yang dimaksud dengan lari? Lalu, atribut apa sajakah yang terlibat dalam kegiatan berlari? Apakah itu menggerakkan kaki atau tangan saja?

2. Kata benda yang tidak eksis di dunia nyata, kata benda imajiner.

Contoh: kuda tanduk, tuyul, peri dan lainnya.

Kata-kata benda tersebut merupakan contoh bahwa kata tidak selalu memiliki kaitan makna dengan segala sesuatu yang kita alami di dunia nyata. Dalam kasus ini, sang pengucap harus terlebih dahulu memisahkan dua jenis dunia yang terdapat di pikirannya, yaitu antara dunia nyata dan dunia imajiner agar mendapatkan makna yang diinginkan.

3. Kata-kata yang tidak termasuk kata benda imajiner maupun fisik.

Contoh: Cinta, benci, indah, dan lainnya.

Semua ini adalah kata benda, meskipun bersifat abstrak. Dan biasanya kata-kata benda tersebut berdampingan dengan kata benda lainnya.

4. Objek yang memiliki makna yang berbeda, tetapi merujuk pada objek yang sama.

Contoh: bintang pagi dan bintang sore.

Dua objek ini memiliki perbedaan dalam hal kenampakkan dan istilah, tetapi merujuk pada objek yang sama.

5. Kata-kata yang secara visual bersangkutan dan objek-objek lainnya yang pernah kita temui.

Contoh: Bangku, bisa berkaitan dengan banyak jenis bangku dengan namanya masing-masing.

Ada dua penjelasan mengenai hal ini: - Yang pertama adalah 'realist', yang berpendapat bahwa semua benda yang disebut dengan nama yang sama memiliki properti yang sama - bahwa ada beberapa hal baku mengenai bangku, bukit, ataupun rumah. - Kedua pandangan 'nominalist', yang berpendapat bahwa setiap kata sama sekali tidak terhubung dengan lainnya, atau mereka memiliki maknanya tersendiri.

6. Kata atau istilah yang memiliki kelas makna yang sudah sewajarnya.

Contoh: Singa adalah singa, kucing adalah kucing, zat kimia, dan lainnya.

Akan tetapi, tidak semua kata yang kita kenal hanya terpaku pada satu macam makna.

Contoh: Bloomfiled memaknai garam sebagai campuran zat $\mathrm{NaCl}$. Tetapi, lazimnya kita mengatakan garam adalah sesuatu yang digunakan untuk memasak sayur, telur dadar, atau lainnya. 
Daftar Pustaka

Cahyono, Bambang Yudi. 1994. Kristal-Kristal Ilmu Bahasa. Surabaya: Airlangga University Press.

Chaer, Abdul. 2007. Linguistik Umum. Jakarta: Rineka Cipta.

Chaer, Abdul. 1994. Pengantar Semantik Bahasa Indonesia. Jakarta: Rineka Cipta.

Kushartanti, Untung Yuwono, dan Multamia RMT Lauder. 2005. Pesona Bahasa Langkah Awal Memahami Linguistik. Jakarta: PT. Gramedia Pustaka Utama.

Amanto, B. S., Umanailo, M. C. B., Wulandari, R. S., Taufik, T., \& Susiati, S. (2019). Local Consumption Diversification. Int. J. Sci. Technol. Res, 8(8), 1865-1869.

Amri, M., Tahir, S. Z. A. B., \& Ahmad, S. (2017). The Implementation of Islamic Teaching in Multiculturalism Society: A Case Study at Pesantren Schools in Indonesia. Asian Social Science, 13(6), 125.

Andini, K. NILAI BUDAYA SUKU BAJO SAMPELA DALAM FILM THE MIRROR NEVER LIES KARYA KAMILA ANDINI.

ARYANA, A. PERBANDINGAN GAYA BAHASA DALAM NOVEL ATHEIS KARYA ACHDIAT KARTA MIHARDJA DAN NOVEL TELEGRAM KARYA PUTU WIJAYA: TINJAUAN STILISTIKA.

Azwan, A. (2018). Politeness strategies of refusals to requests by Ambonese community. LINGUA: Jurnal Bahasa, Sastra, Dan Pengajarannya, 15(1), 1-6. 
Bin-Tahir, S. Z., Atmowardoyo, H., Dollah, S., Rinantanti, Y., \& Suriaman, A. (2018). MULTILINGUAL AND MONO-MULTILINGUAL STUDENTS'PERFORMANCE IN ENGLISH SPEAKING. Journal of Advanced English Studies, 1(2), 32-38.

Bin Tahir, S. Z. (2017). Multilingual teaching and learning at Pesantren Schools in Indonesia. Asian EFL Journal, 89, 74-94.

Bin Tahir, S. Z. (2015). The attitude of Santri and Ustadz toward multilingual education at Pesantren. International Journal of Language and Linguistics, 3(4), 210-216.

Bin-Tahir, S. Z., \& Rinantanti, Y. (2016). Multilingual lecturers' competence in english teaching at the university of Iqra Buru, Indonesia. Asian EFL Journal, 5, 79-92.

Bin-Tahir, S. Z., Saidah, U., Mufidah, N., \& Bugis, R. (2018). The impact of translanguaging approach on teaching Arabic reading in a multilingual classroom. ljaz Arabi Journal of Arabic Learning, 1(1).

Bin-Tahir, S. Z., Bugis, R., \& Tasiana, R. (2017). Intercultural Communication of a Multicultural Family in Buru Regency. Lingual: Journal of Language and Culture, 9(2), 8.

Djamudi, N. L., Nurlaela, M., Nazar, A., Nuryadin, C., Musywirah, I., \& Sari, H. (2019, October). Alternative social environment policy through educational values in Kafi'a's customary speech to the kaledupa community of Wakatobi Island, Indonesia. In IOP Conference Series: Earth and Environmental Science (Vol. 343, No. 1, p. 012118). IOP Publishing.

Indonesia, K. K. D. B. Morfologi Bahasa Indonesia.

Iye, R., Susiati, S., \& Karim, K. (2020). Citra Perempuan dalam Iklan Sabun Shinzui. Sang Pencerah: Jurnal Ilmiah Universitas Muhammadiyah Buton, 6(1), 1-7.

Iye, R. (2018). Tuturan dalam Prosesi Lamaran Pernikahan di Tomia Kabupaten Wakatobi. Jurnal Totobuang, 6(2).

Iye, R. H. NILAI-NILAI MORAL DALAM TOKOH UTAMA PADA NOVEL SATIN MERAH KARYA BRAHMANTO ANINDITO DAN RIE YANTI. TELAGA BAHASA,(7), 2, 195-206.

Karim, K., Maknun, T., \& Abbas, A. (2019). Praanggapan Dalam Pamflet Sosialisasi Pelestarian Lingkungan Di Kabupaten Wakatobi. Jurnal IImu Budaya, 7(2), 241-247.

La Djamudi, N., \& Nazar, A. (2020, May). Wolio's Oral Literary Form the Character of Millennial in Buton Islands. In 1st Borobudur International Symposium on Humanities, Economics and Social Sciences (BISHESS 2019) (pp. 132-135). Atlantis Press.

Lafamane, F. (2020). Tata Bahasa Sistemik Fungsional (Suatu Pandangan).

Lafamane, F. (2020). Perkembangan Teori Sastra (suatu Pengantar). OSF Preprints. July, 25.

Lafamane, F. (2020). Tata Bahasa Fungsional (functional Grammar). 
Lafamane, F. (2020). Fenomena Penggunaan Bahasa Daerah di Kalangan Remaja.

Lafamane, F. (2020). ANTROPOLINGUISTIK (Hubungan Budaya dan Bahasa).

Lafamane, F. (2020). FONOLOGI (Sejarah Fonologi, Fonetik, Fonemik).

Mansyur, F. A., \& Suherman, L. A. (2020). The Function of Proverbs as Educational Media: Anthropological Linguistics on Wolio Proverbs. ELS Journal on Interdisciplinary Studies in Humanities, $3(2), 271-286$.

Namlea, B. CONCEPT OF CONFLICT IN THE FILMS "AISYAH BIARKAN KAMI BERSAUDARA" BY HERWIN NOVIANTO Susiati.

Sadat, A., Nazar, A., Suherman, L. O. A., Alzarliani, W. O. D., \& Birawida, A. B. (2019, October). Environmental care behavior through e-jas model with science edutainment approach. In IOP Conference Series: Earth and Environmental Science (Vol. 343, No. 1, p. 012126). IOP Publishing.

Sadat, A., Sa'ban, L. M. A., Suherman, L. O. A., Bahari, S., Ibrahim, T., \& Zainal, M. (2019, October). Internalization characters of environmental care and disaster response through care partner schools. In IOP Conference Series: Earth and Environmental Science (Vol. 343, No. 1, p. 012125). IOP Publishing.

Salamun, T. (2018). DEIKSIS PERSONA BAHASA INDONESIA DIALEK AMBON [Personal Deixes of Indonesian Leanguage With Ambonese Dialect]. Totobuang, 5, 325-339.

Salamun, T. (2018). RELASI KEKERABATAN BAHASA HITU, WAKAL, MORELA, MAMALA, DAN HILA DI PROVINSI MALUKU [The Family Relationship Language Hitu, Wakal, Morela, Mamala, and Hila in Maluku Province].

Suherman, L. A. (2018). The Analysis of Metaphorical Domain on English "Stab Verb" in Corpora. ELS Journal on Interdisciplinary Studies in Humanities, 1(1), 52-58.

Suherman, L. O. A., Salam, S., Mursanto, D., Efendi, A., Bahar, S. B., \& Kanna, T. (2019, October). The effect of open-air curing on compressive strength of geopolymer mortar containing laterite soil and slaked lime. In IOP Conference Series: Earth and Environmental Science (Vol. 343, No. 1, p. 012133). IOP Publishing.

Susiati, S., \& Iye, R. (2018). Kajian Geografi Bahasa dan Dialek di Sulawesi Tenggara: Analisis Dialektometri. Gramatika: Jurnal IImiah Kebahasaan dan Kesastraan, 6(2), 137-151.

Susiati, S. Dialektometri Segitiga: Hubungan Kekerabatan Bahasa Di Sulawesi Tenggara (Bahasa Wakatobi, Bahasa Cia-Cia, Bahasa Pancana, Bahasa Kioko, Bahasa Tolaki).

Susiati, S. (2020). Nilai Pembentuk Karakter Masyarakat Wakatobi Melalui Kabhanti Wa Leja.

Susiati, S., Iye, R., \& Suherman, L. O. A. (2019). Hot Potatoes Multimedia Applications in Evaluation of Indonesian Learning In SMP Students in Buru District. ELS Journal on Interdisciplinary Studies in Humanities, 2(4), 556-570. 
Susiati, S. (2020). Internal Recontruction Bugis Language and Makassar Language.

Susiati, S. (2018). Homonim bahasa kepulauan tukang besi dialek kaledupa di kabupaten wakatobi [the homonymon of tukang besi island languange in kaledupa dialect at wakatobi regency]. Totobuang, 6 (1), 109, 123.

Susiati, S. (2020). Emosi Verbal Suku Bajo Sampela.

Susiati, S. (2020). Fenomena Tuturan Emosi Verbal Bahasa Indonesia Suku Bajo Sampela.

Susiati, S. (2020). Nilai Budaya Suku Bajo Sampela Dalam Film The Mirror Never Lies Karya Kamila Andini.

Susiati, S. (2020). Konsep Pertentangan Dalam Film" Aisyah Biarkan Kami Bersaudara" Karya Herwin Novianto.

Susiati, S. (2020). Strategi AMBT untuk Meningkatkan Kemampuan Membaca Pemahaman Interpretatif Siswa Kelas IV SD Negeri 3 Namlea Kabupaten Buru.

Susiati, S. (2020). Fungsi Konatif Pada Iklan Mesin Cuci Hole-Less Tub Dari Sharp: Analisis Wacana Kritis.

Susiati, S. (2020). GAYA BAHASA SECARA UMUM DAN GAYA BAHASA PEMBUNGKUS PIKIRAN.

Susiati, S. (2020). The Concept Of Togetherness In The Films" Aisyah Biarkan Kami Bersaudara" By Herwin Novianto.

Susiati, S. (2020). Konsep Kebersamaan Dalam Film" Aisyah Biarkan Kami Bersaudara" Karya Herwin Novianto.

Susiati, S. (2020). Teori dan Aliran Linguistik: Tata Bahasa Generatif.

Susiati, S. (2020). Metode Pembelajaran Bahasa Indonesia: Sosiodrama.

Susiati, S. (2020). Rekontruksi Internal Bahasa Bugis dan Bahasa Makassar: Linguistik Komparatif.

Susiati, S. Bahan Ajar: Psikolinguistik.

Susiati, S. (2020). PENTINGNYA MELESTARIKAN BAHASA DAERAH.

Susiati, S. (2020). Morfologi Kelas Kata Dalam Bahasa Indonesia.

Susiati, S. (2020). Semantik: Teori Semantik, Relasi Makna, Marked, Dan Unmarked.

Susiati, Y. T. Risman Iye. A. Kesantunan Imperatif Bahasa Indonesia Suku Bajo Sampela: Balai Pembinaan dan Pengembangan Bahasa. 2018. Kongres Bahasa Indonesia (No. 12, pp. 1-6). Report.

Susiati, S. (2020). Internal Recontruction Bugis Language and Makassar Language.

Susiati, S. (2020). Kesantunan Imperatif Bahasa Melayu Ambon. 
Susiati, S. (2020). Gaya Bahasa Secara Umum Dan Gaya Bahasa Pembungkus Pikiran: Stilistika.

Susiati, S. (2020). Tuturan Kesantunan Imperatif Bahasa Indonesia Suku Bajo Sampela.

Susiati, S. (2020). Nilai Budaya Suku Bajo Sampela Dalam Film The Mirror Never Lies Karya Kamila Andini.

Susiati, S. (2020). Pengaplikasian Multimedia Hot Potatoes Dalam Evaluasi Pembelajaran Bahasa Indonesia Pada Siswa SMP Negeri 9 Buru.

Susiati, S., \& lye, R. (2018). Kajian Geografi Bahasa dan Dialek di Sulawesi Tenggara: Analisis Dialektometri. Gramatika: Jurnal IImiah Kebahasaan dan Kesastraan. 6 (2), 137-151.

Susiati, S. (2020). Kaidah Fonologi Bahasa Indonesia.

Susiati, S. (2020). Wujud Morfologi Bahasa Indonesia.

Susiati, S. (2020). Makian Bahasa Wakatobi Dialek Kaledupa.

Susiati, S. (2020). Eksistensi Manusia Dalam Film" Aisyah Biarkan Kami Bersaudara" Karya Herwin Novianto.

Susiati, S., \& Mufidati, E. (2020). An Indonesian National English Textbook for Secondary Level: Is It Qualified Enough?. Jurnal VARIDIKA, 32(1), 118-124.

Susiati, S. NILAI BUDAYA SUKU BAJO SAMPELA DALAM FILM THE MIRROR NEVER LIES.

Susiati, S. (2020). Konsep Keterasingan Dalam Film" Aisyah Biarkan Kami Bersaudara" Karya Herwin Novianto.

Susiati, S. (2020). Concept Of Conflict In The Films "AISYAH BIARKAN KAMI BERSAUDARA" By Herwin Novianto.

Susiati, S. (2020). Embrio Nasionalisme Dalam Bahasa dan Sastra.

Susiati, S. PERWUJUDAN SIMILE OLEH MERARI SIREGAR DALAM NOVEL AZAB DAN SENGSARA.

Susiati, S. (2020). Concept Of Conflict In The Films "AISYAH BIARKAN KAMI BERSAUDARA" By Herwin Novianto.

Susiati, S. (2020). Nilai Pembentuk Karakter Masyarakat Wakatobi Melalui Kabhanti Wa Leja.

Susiati, S. MAKNA DAN FUNGSI EMOSI MAHASISWA KOTA BAUBAU DALAM RANAH DEMONSTRASI (The Meaning and Emotional Function of BauBau City Students in the Demonstration Plan).

Tahir, S. Z. A. B. (2017). Pengembangan Materi Multibahasa untuk Siswa Pesantren. Unpublish dissertation.

Tahir, S. Z. B. (2015). Multilingual Teaching And Learning At Pesantren. 14 Asian EFL Journal Conference. 
Tenriawali, A. Y. (2018). Representasi korban kekerasan dalam teks berita daring tribun timur: analisis wacana kritis [the representation victims of violence in tribun timur online news text: critical discourse analysis]. TOTOBUANG, 6 (1), 1, 15.

Yusdianti, A. (2020). THE REPRESENTATION VICTIMS OF VIOLENCE IN TRIBUN TIMUR ONLINE NEWS TEXT: CRITICAL DISCOURSE ANALYSIS. 